Katarzyna GAWDZIŃSKA ${ }^{1}$

Rafał ŁAPAWA ${ }^{2}$

Pawel SZYMAŃSKI ${ }^{3}$

Artur BEJGER ${ }^{4}$

Krzysztof NOZDRZYKOWSKI ${ }^{5}$

\title{
CHARACTERISTICS OF PRODUCTION METHODS OF ALUMINIUM AND MAGNESIUM MATRIX COMPOSITE CASTINGS
}

\begin{abstract}
Light metal (aluminium and magnesium) matrix composites in particular are being increasingly used in various kinds of transportation vehicles. The properties of final products are closely related to the employed production technology. This paper presents a brief review of the technologies used in aluminium and magnesium matrix composite casting, with a focus on the risks and benefits of each technology.
\end{abstract}

Keywords: metal composites, manufacturing technologies, aluminium, magnesium

\section{Introduction}

Metal composites, especially the reinforced composites, are not easily available or widely applied in various technical solutions. This is largely due to their high manufacturing costs. Studies carried out in different countries aim to simplify the methods of production of composites as well as to replace the expensive specific reinforcement fibres with less expensive and more readily available alternatives while maintaining the required mechanical and physical properties of the composites. The strive to replace homogeneous materials with composites results from studies on light metal matrix composite materials. For example, as it can be seen in Table 1, the mechanical properties of aluminium and magnesium alloys are characterised by significantly higher values when compared to the properties of $\mathrm{Al}$ or $\mathrm{Mg}$ matrix fibre composites [1-3].

${ }^{1}$ Autor do korespondencji/corresponding author: Katarzyna Gawdzińska, Maritime University of Szczecin, 2-4 Willowa St., 71-650 Szczecin, e-mail: k.gawdzinska@am.szczecin.pl

2 Rafał Łapawa, Military University of Technology in Warsaw, e-mail: rafal.lapawa@ wat.edu.pl

${ }^{3}$ Paweł Szymanski, Institute of Materials Technology, Poznan, e-mail: pawel.szymanski@put. poznan.pl

4 Artur Bejger, Maritime University of Szczecin, e-mail: a.bejger@am.szczecin.pl

${ }^{5}$ Krzysztof Nozdrzykowski, Maritime University of Szczecin, e-mail: k.nozdrzykowski@am. szczecin.pl 
Table 1. Standard properties of light alloys and aluminium and magnesium matrix composites

Tabela 1. Standardowe właściwości stopów lekkich i kompozytów na osnowie aluminium i magnezu

\begin{tabular}{|l|c|c|c|c|c|c|}
\hline \multicolumn{1}{|c|}{ Materials } & $\begin{array}{c}\text { Volume fraction } \\
\text { of fibres }[\%]\end{array}$ & $\begin{array}{c}\text { Density } \rho \\
{\left[\mathrm{g} / \mathrm{cm}^{3}\right]}\end{array}$ & $\begin{array}{c}\mathrm{Rm} \\
{[\mathrm{MPa}]}\end{array}$ & $\begin{array}{c}\mathrm{Rm} / \rho \\
{[\mathrm{km}]}\end{array}$ & $\begin{array}{c}\mathrm{E} \\
{[\mathrm{GPa}]}\end{array}$ & $\begin{array}{c}\mathrm{E} / \rho \\
{[\mathrm{km}]}\end{array}$ \\
\hline Mg-B composite & 75 & 2.4 & 1320 & 55.0 & 340 & 14200 \\
\hline A1-B composite & 30 & 2.7 & 1010 & 37.5 & 180 & 6660 \\
\hline Al-SiC composite & 22 & 3.1 & 700 & 22.6 & 230 & 7410 \\
\hline Mg-5.5 Zn-0.5 Zr alloy & - & 1.8 & 290 & 16.0 & 45 & 2500 \\
\hline Al-5.6 Zn-2.5 Mg alloy & - & 2.7 & 570 & 21.1 & 70 & 2590 \\
\hline
\end{tabular}

For instance, comparing the magnesium alloy with the Mg-B composite, it can be concluded that the tensile strength of the composite exceeds the strength of the non-reinforced alloy almost fivefold and the modulus of elasticity (E) almost eightfold. Since the specific density of magnesium composites exceeds the specific density of the magnesium alloy only by less than $40 \%$, profiles and readymade elements manufactured from such composites can be applied in critical construction elements of the aircraft and automotive industries. In result, by reinforcing aluminium or its alloys with high-temperature boron fibres, we are able to obtain a construction material from which some engine parts can be manufactured [1-3]. The composite is characterised by nearly doubled tensile strength and almost three times higher modulus of elasticity in comparison to the non-reinforced matrix material. Such valuable properties of the fibrous $\mathrm{Mg}$ and $\mathrm{Al}$ matrix composites are due to their reinforcement by means of boron fibres, which are characterised by very high tensile strength. Because of their cost, however, they are used only in the cases where composites are required to possess high strength and high stiffness.

The Al-carbon fibre composites have very favourable specific tensile strength and stiffness parameters. They are currently used in the manufacture of aircraft, missiles and other military equipment. The basic technology for the production of these composites is continuous liquid metal infiltration, which aims to produce $\mathrm{Al}$ (or $\mathrm{Al}$ alloy)/carbon fibre 'wires' or tape, and their subsequent hot pressing or modified extrusion pressing. The result is good bonding between the fibres and the matrix. The tensile strength of such a composite is approx. $700 \mathrm{MPa}$ and its Young's modulus equals approx. $150 \mathrm{GPa}$ with the density of approx. $2.35-2.80 \mathrm{~g} / \mathrm{cm}^{3}$, depending on the proportion of carbon fibres. Higher values are exhibited by Al-B composites (Tab. 1) obtained using a similar technology [4]. Aluminium matrix composites reinforced with ceramic $\mathrm{Al}_{2} \mathrm{O}_{3}$ fibres, containing $60 \%$ aluminium oxide, achieve $R_{m}=655 \mathrm{MPa}$ and elastic modulus $E=260 \mathrm{GPA}$ with a density of $3.45 \mathrm{~g} / \mathrm{cm}^{3}$ [4]. The structure of an AlSi11 alloy matrix composite reinforced with $\mathrm{Al}_{2} \mathrm{O}_{3}$ fibre is shown in Fig. 1. 
Fig. 1. Cross section of a ceramic fibre reinforced composite

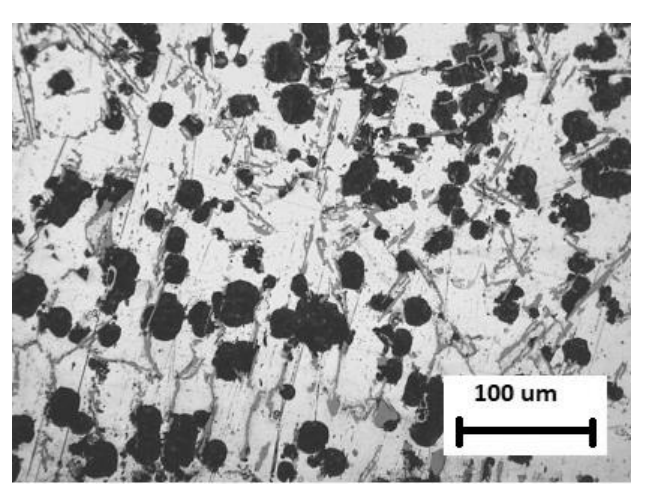

Due to the fact that reinforcements in the form of continuous fibres (carbon or aluminium oxide fibres) are very expensive, they have been gradually replaced by steel fibre reinforcing elements. The density of the Al-steel fibre composite is about $3.98 \mathrm{~g} / \mathrm{cm}^{3}$ and its tensile strength is $R_{m}=1230 \mathrm{MPa}$ at room temperature and above, which enables replacement of some titanium alloys used in aircraft and the automotive industry with this type of composite [5-6]. The properties of final products are closely related to the technology employed in their production. This paper presents a brief description of technologies used in aluminium and magnesium matrix composite casting with a focus on the risks and benefits of each technology.

\section{Characteristics of production methods of aluminium and magnesium matrix composite castings}

Composite material technologies, especially of metal composites, are considered to be very difficult to implement practically. This is due to the need to meet the requirements that lead to obtaining the new material by means of a combination of at least two chemically distinct materials in such a way that, while maintaining an appropriate and permanent bonding of the components, a clear boundary between them is maintained and that the distribution of the reinforcing components throughout the matrix is as uniform as possible. The characteristics of the material obtained in such a way are determined by the volume fraction of the components and their physical and mechanical parameters [7]. Creation of a strong bond between two distinct components requires the use of high temperatures or very high pressure forces, or the combination of these two factors at the same time. In such conditions, there is a risk of changes to the mechanical characteristics of the materials to be joined, occurrence of unwanted reaction products in the vicinity of the bond, or mechanical damage to the fragile reinforcement fibres due to large pressure forces during their permanent bonding to the 
matrix [8-10]. In order to limit the possibility of the occurrence of these negative phenomena, the technology used for composite production should be selected on the basis of the type and form of the components to be joined. Listed below are the main methods for obtaining metal matrix composites [5-6]:

1. Continuous-reinforced Metal Matrix Composites (cMMCs)

- casting methods,

- thermal spraying,

- powder cloth,

- foil-fibre-foil method.

2. Dispersion-reinforced Metal Matrix Composites (dMMCs)

- casting processes for the production of composite materials,

- sand casting,

- die-casting,

- special methods

- full mould methods (lost-foam, expandable pattern casting),

- squeeze casting,

- injection moulding,

- pressure infiltration,

- spontaneous infiltration.

- powder metallurgy

- solid/liquid pressing,

- kinetic blending,

- in situ processes.

The output products may take the forms of ingots, billets, granules, metal sheets, profiles, slabs or products of sizes close to the finished product. These products are then formed by means of melting, plastic processing (forging, extrusion), machining, joining (brazing, welding), often using non-traditional methods and modern technology.

Special attention should be paid to the processes of obtaining metal matrix composites, including the aluminium alloy matrix, by means of pressure infiltration. At the present stage of technological development, this process is probably the most cost-effective and versatile in the production of fibre and dispersion-reinforced composite materials. The advantages of this method are: relatively low cost of the matrix, limited risk of mechanical degradation of the reinforcement, production speed, simplicity of equipment (as in regular casting), as well as the possibility of precise reproduction of shapes and surfaces which significantly reduces the required machining and finishing. Other advantages arising from the preservation of limits in the chemical nature of the matrix/reinforcement structure are: shortened contact times, i.e. reduced interaction between the reinforcement and matrix thanks to the quicker infiltration achieved by means of the applied pressure, increased intensity of the heat exchange processes and limited outflow 
since the infiltration occurs at the temperature below the matrix melting or liquidus point. In the case of pressure infiltration, the potential appearance of unfiltered (unsaturated) parts is significantly reduced as the liquid matrix metal reinforces the porous areas under pressure by means of a properly adjusted temperature field, which results in a highly fragmented microstructure. The main shortcomings of pressure infiltration that were identified are higher requirements in terms of tooling and the equipment generating the external pressure. Problems also arise in the case of large or locally reinforced castings.

The main process parameters to be carefully monitored include [3-6]: initial temperature of the preform, form and metal, volume fraction of reinforcement, the applied pressure and infiltration rate (these are not independent). Physical circumstances, such as continuity and conservation of heat and mass, are important factors considered in the determination of boundary conditions. Designing mathematical models of various infiltration processes leads to complicated solutions, which is due to the complexity of the interaction between the processes of matrix solidification, liquid metal flows, heat exchange, etc. Despite this, it is possible to obtain a satisfactory agreement between the calculations and experimental data.

The practical consequences of the physics of the process result from the fact that preformed infiltration is an irreversible process somehow independent of the rate of pressure rise. Low temperatures of preform and form, combined with high pressure values at cycle end, result in reduction of unwanted interactions within the reinforcement-matrix system. High pressures should only be applied when the whole preform (process, state?) is already pre-saturated - this helps to avoid preform deformation. The preform temperature must be higher than the matrix liquidus temperature and the preform should be chemically inert which reduces the segregation of structural components of the matrix. Infiltration rate is largely dependent on the initial temperature of the preform (if it is below the matrix liquidus temperature), volume fraction of reinforcement and overheat temperature of the metal. The conditions of external cooling (heat removal intensity) and the methods of pressure application determine the maximum infiltration distance.

There are also more practical aspects to the process. The production of preforms, as a rule, is complex and expensive. It involves pressing or suction of a specially prepared suspension of fibres in a solution, drying, burning, sometimes arranging the continuous fibres in the form and joining them using a binder or complex spatial structures. The resulting volume fraction of fibres depends on the type of reinforcement and the selected method of production. The achievable maximum is $50-60 \%$ of volume for oriented fibres, approx. $50 \%$ for equiaxial particles of similar size and below $40 \%$ for non-oriented fibres and whiskers. The finished preforms are then arranged in the form, often together with appropriate fillers or cores. The location of the preforms is determined directly by the requirements established for the local reinforcement of the final product. The gas accu- 
mulated in the preform on the infiltration front, as a rule, is removed by means of ventilation channels in the form. In the case of pressure-vacuum gas infiltration, what prevents the flow of liquid metal into the vacuum system are the porous ceramic fittings (of high ceramic content and small channels) [6].

The infiltration pressure can be applied mechanically by means of an injection plunger (as is the case of squeeze casting, where the plunger is a part of the form, or injection moulding, where the plunger injects the metal into the mould cavity) or using gas. The injection plunger diameter and the dimensions of the gating for pressure casting of composites are typically higher than in a monolithic casting. Hence, the mould locking forces, as well as the wall thickness of the pressure forms should be higher. The forms are made of tool steel and are designed for hot working temperatures. Their working temperature is maintained in the range of $200-300^{\circ} \mathrm{C}$, which prevents the adhesion of molten metal to the form and provides quicker solidification. In the case of high pressures, the gas is not as effective or as fast as its mechanical equivalent. However, in the case of gas infiltration, hot melt ceramic materials can also be applied.

Shrinkage porosity is usually eliminated by directional solidification combined with pressure application that provides better support for casting zones, which are the deepest within the structure or last to solidify. Solidification can be uneven if the casting includes both reinforced and monolithic zones. In this case, the conductivity, heat capacity and latent heat of solidification of the composite are different than in the case of the matrix. Thus, the mechanisms of solidification in various zones of a locally reinforced casting may differ substantially. In the case of mechanical pressure actuators, the application of a porous insulating coating on the inner walls of the mould allows for better management of the process of heat release through the form walls. The coating works as an insulator prior to the infiltration and provides faster heat dissipation after the process.

There is a possibility to adapt the basic processes of moulding to obtain continuous-reinforced composite castings. For example, using techniques similar to the above-mentioned methods of preventing the penetration of metal into the vacuum system, in the case of the gas actuator, and fibrous preform infiltration can be performed.

Centrifugal casting is another process which enables the application of pressure (in this case resulting from the centrifugal effect) for the infiltration of preforms. It involves the application of a device that uses alternating magnetic field inducing eddy currents in the liquid metal, which in turn leads to the Lorentz force acting directly on the infiltration front in the preform. The ALCOA Company also applies pressure casting for obtaining shaped castings using DURALCAN ingots (15 to $20 \% \mathrm{SiC}$ ), as well as materials containing $55-60 \% \mathrm{SiC}$. This method is less expensive than classical pressure casting and provides better properties of the obtained composite. The obtained castings require virtually no machining [6]. 
Gas infiltration processes were also examined in Japan. The preforms used in the studies contained woven or film-laminated structures, largely made of stiff, large diameter fibres oriented in such a way as to achieve the desired combination of properties. The applied pressure helped to achieve better contact between the metal and the reinforcement and eliminated the problems of wetting that occur in other processes.

Casting under high hydrostatic pressure (squeeze casting) involves placing the heated preform inside a mould cavity into which the metal is poured and then the pressure is applied by means of an injection plunger. High pressures used in this method help to produce castings with enhanced properties and to eliminate any structural defects. This method provides high economic efficiency and an opportunity for full automation, which is particularly useful in large scale production.

The obtained pressure values are usually in the range of 50-150 MPa, but the devices and tooling are quite expensive. The mathematical modelling of heat transfer and metal flow in the process of squeeze casting enabled to determine the factors that affect the optimum values of the threshold pressure, its increment rate and infiltration depth. These include: volume fraction and size of fibres, preform, form, and metal temperature, infiltration rate, the method of external pressure application, the exothermic effects occurring after preform heat treatment, and others. The threshold pressure reaches only a few atmospheres, while the pressure required to eliminate gas and shrinkage porosity should be several times higher. Another distinguishing feature of this process is its declared isothermal, partial re-melting of the composite that contributes to a quicker change in the shape of the original matrix dendrites towards their spheroidisation and a significant reduction in the resistance of the suspension against deformation [6].

The processes associated with further processing of the semi-finished composites require less complex machines, devices and tooling. In order to produce composites on a large scale, complete and precise control of the process is required. The main variables in the process include: overheating temperature of fibres and metal, the type of alloying elements, metal quality, temperature of the shaping device, time between filling the form, closing it, and the applied pressure, pressure rate and time, and speed of injection plunger $[8,9,11,12]$. The remaining factors of the process that can be determined include: time of direct contact of liquid metal with the form (minimised), infiltration rate (in combination with minimised segregation), spatial structure of the preform providing minimum saturation and deformation resistance of the orientation of the fibres in high pressure and high temperature conditions. The design of the preform should also take into account minimisation of the volume fraction of fibres (yet still providing the reinforcement effect), which contributes to a drastic reduction in the cost of its manufacture. Degassing of the ceramic suspension of the preform material immediately following mixing contributes to a significant increase (of about 26\%) in the composite's resistance to cracking. 
In the case of particulate composites, centrifugal casting involves pouring the mixture of particles in the molten metal into a mould rotating at speeds of several thousand revolutions per minute. The size of the centrifugal force is controlled by the rotational speed. For example, an aluminium suspension initially containing $10 \% \mathrm{SiC}$ (Fig. 2) can be cast with an outer layer containing 30\% SiC (Fig. 3). By changing the particle size and selecting the kind of reinforcement/matrix composition, it is possible to adjust the type and shape of the final composite; the heavier particles will gather on the outer surface of the cast cylinder, while the lighter particles will accumulate on the inner surface. Some of the most important process parameters are: difference in density between the particles and the matrix liquid metal, size of the centrifugal form, and the pouring temperature $[6,8,9,11,12]$.
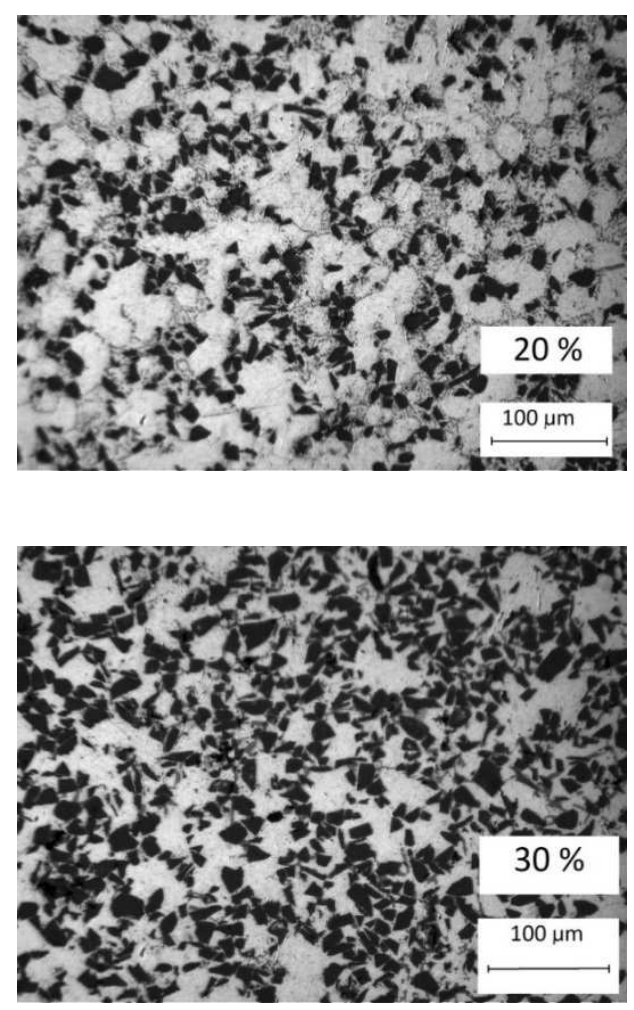

Fig. 2. Structure of the DURALCAN F3S.20S composite

Fig. 3. Surface layer structure of the F3S.20S composite cast centrifugally

In the case of the manufacturing method of magnesium matrix composites, it is necessary to take into consideration the physical state of the matter, also called the thixotropic state, in which the liquid and the solid exist alongside each other and which is characterised by low suspension viscosity. This state can be achieved by applying shear stress to the alloy heated slightly below the liquidus tempe- 
rature. The pre-conditioned ceramic fittings (barrels) containing reinforcing particles of $\mathrm{SiC}, \mathrm{Al}_{2} \mathrm{O}_{3}, \mathrm{~B}_{4} \mathrm{C}$ or AZ91D magnesium alloy granules in a semi-solid state are mixed using a shear bolt heated to a high temperature which leads to the formation of a semi-solid suspension, which is then injected into the mould cavity at high speed (20-50 $\mu$ sec/injection) under the pressure of $40 \mathrm{MPa}$. The form is filled completely with the injection front in a semi-solid state, which provides much lower shrinkage porosity in the final product compared to the pressure casting of the standard liquid metal. Also, the distribution of particles seems satisfactory. Because of the elimination of the additional melting operation, the cost of the process is considerably decreased. In addition, a lower metal temperature (below liquidus) contributes to extending the service life of the mould and the resulting productivity growth. The obtained products can be processed thermally, as their porosity is substantially reduced $[9,10,13-18]$.

Moreover, there is another method of quasi-gravitational infiltration known as Primex. The molten aluminium alloy is placed in contact with the ceramic preform which is typically made of $\mathrm{SiC}$ or $\mathrm{Al}_{2} \mathrm{O}_{3}$ particles. This process is distinguished by two characteristic features: the matrix metal contains 3-10\% Mg mass and is performed in a protective atmosphere (nitrogen) at an elevated temperature. In these conditions, spontaneous preform infiltration occurs. The volume fraction of the reinforcement can be substantial and can reach $50 \%$ or more. This method has found applications in the production of fittings, temperature control systems and electronic microcircuit units $[3-4,6,10]$.

\section{Summary}

The required operational properties combined with low specific weight are extremely beneficial and desirable in the design of almost every system and element of a modern vehicle. Therefore, it is widely understood that transport is the area where composites may find increasingly wider application [6, 7, 13-17]. Table 2 presents existing or potential areas of use of composite materials in the widely understood transportation industry. Composite materials, although relatively slowly, are steadily entering the modern automotive industry and their number is growing every year. The most commonly used composite materials in the automotive industry are silicon carbide and aluminium oxide fibre-reinforced aluminium alloys. In accordance with global trends, the primary area of application of $\mathrm{Al}$ and $\mathrm{Mg}$ alloy matrix composites in cars are parts of the driving mechanism including the engine and braking, steering and suspension systems. One of the products of high quality made of composites (especially aluminum-ceramic composites [18]) may be foams. Composite foams produced at the Maritime University of Szczecin are subjects of research in the area of fire insulation and fillings in ship bulkheads. An example of manufactured foams is shown in Fig. 4. 
Table 2. Scope of application of metal composite materials in the transportation industry and the resulting advantages $[3,4,6,7,10-17]$

Tabela 2. Obszar zastosowań metalowych materiałów kompozytowych w przemyśle środków transportu oraz wynikające z tego korzyści [3, 4, 6, 7, 10-17]

\begin{tabular}{|c|c|c|c|c|c|c|c|c|c|}
\hline \multirow[b]{2}{*}{$\begin{array}{c}\text { Existing } \\
\text { or potential uses }\end{array}$} & \multicolumn{9}{|c|}{ Advantages } \\
\hline & 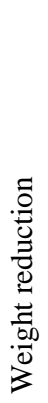 & 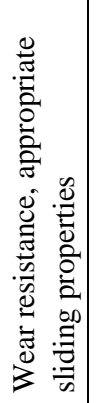 & 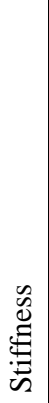 & 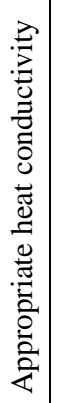 & 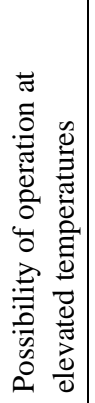 & 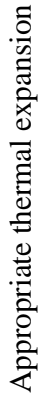 & 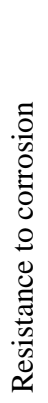 & 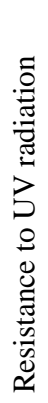 & 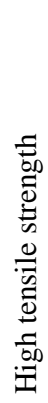 \\
\hline Gear parts & $*$ & $*$ & & & & & $*$ & & \\
\hline Turbine parts & $*$ & $*$ & & & $*$ & & & & $*$ \\
\hline Aerospace segment & $*$ & & $*$ & $*$ & & & & $*$ & \\
\hline Bearings & $*$ & $*$ & & & & & $*$ & & $*$ \\
\hline Boat masts & $*$ & & $*$ & & & & & & $*$ \\
\hline $\begin{array}{l}\text { Connecting elements (bolts and nuts) working in } \\
\text { chemically aggressive environments }\end{array}$ & $*$ & & & & & & $*$ & & $*$ \\
\hline Aircraft landing gear & $*$ & & $*$ & & & & & & $*$ \\
\hline Land vehicles & $*$ & & & & & & & & $*$ \\
\hline Marine vehicles & $*$ & & $*$ & & & & $*$ & & \\
\hline Aircraft covering & $*$ & & & & & & & & $*$ \\
\hline Worm drives & $*$ & $*$ & & & & & & & $*$ \\
\hline Engine cylinder liners & $*$ & $*$ & $*$ & & & $*$ & & & $*$ \\
\hline Brake discs & $*$ & $*$ & & & & & & & \\
\hline Pistons & $*$ & $*$ & & $*$ & $*$ & $*$ & & & $*$ \\
\hline
\end{tabular}
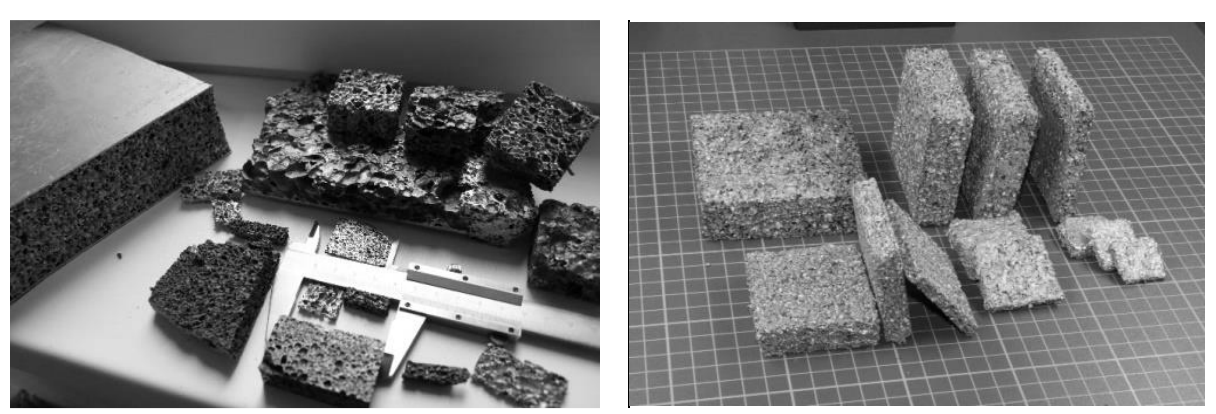

Fig. 4. Foams produced at the Maritime University of Szczecin (AlSi9/SiC composite) 


\section{References}

[1] Suchy J.S.: Kompozyty odlewane, CIAFT, 1995.

[2] Sobczak J., Wojciechowski A.: Zastosowanie materiałów kompozytowych na bazie aluminium w przemyśle środków transportu, Forum Techniczne Instytutu Transportu Samochodowego, Warszawa 1996.

[3] Łapawa R.: Kompozyty z osnową aluminiową jako perspektywiczne tworzywo dla przemysłu motoryzacyjnego - studium wsparte eksperymentem, Praca magisterska, Wojskowa Akademia Techniczna, Warszawa 2004.

[4] Ciszewski B., Przetakiewicz W.: Nowoczesne materiały stosowane w technice, WAT, Warszawa 1989.

[5] Sobczak J., Wojciechowski A.: Zastosowanie materiałów kompozytowych na bazie aluminium w przemyśle środków transportu, Forum Techniczne Instytutu Transportu Samochodowego, Warszawa 1996.

[6] Sobczak J., Metalowe materiały kompozytowe. Stan aktualny i perspektywy rozwoju w świetle polityki naukowej, technologii i praktyki przemysłowej Stanów Zjednoczonych, Instytut Odlewnictwa, Kraków 1996.

[7] Zapłata J., Pajor M.: The influence of presumed border conditions on FEM thermal analysis results based on the example of an LNG tank support saddle, Advances in Mechanics, Theoretical, Computational and Interdisciplinary Issues, Kleiber M. et al. edit., CRC Press/Balkena, London 2016, pp. 601-604.

[8] Dyzia M., Dolata A.J., Śleziona J.: Preliminary analysis of aluminium matrix compositions for composites reinforcement with carbon fibres, Steel Research Int., 83 (2012) 981-987.

[9] Gawdzinska K., Bryll K., Nagolska D.: Influence of heat treatment on abrasive wear resistance of silumin matrix composite castings, Arch. Metall. Mater., 61 (2016) 177-182.

[10] Koniuszewska A., Naplocha K.: Microwave assisted self-propagating high-temperature synthesis of Ti2AlC max phase, Compos. Theory Pract., 16 (2016) 109-112.

[11] Wu S., Liu X., Yeung K.W.K., Liu C., Yang X.: Biomimetic porous scaffolds for bone tissue engineering, Mater. Sci. Eng., 80 (2014) 1-36.

[12] Dolata A.: Centrifugal castings locally reinforced with porous $\mathrm{Al}_{2} \mathrm{O}_{3}$ preform, Arch. Metall., Mater., 59 (2014) 345-348.

[13] Chybowski L.: A New approach to reliability importance analysis of complex technical systems, J. Polish CIMAC, 6 (2011) 65-72.

[14] Chybowski L.: Application of external events vectors for defining reliability structure of fishing vessels power, Propulsion and technological plants. Polish J. Environ. Studies, 18 (2009) 45-50.

[15] Gawdzińska K., Chybowski L., Przetakiewicz W.: Proper matrix-reinforcement bonding in cast metal matrix composites as a factor of their good quality, Arch. Civil Mech. Eng., 16 (2016) 553-563.

[16] Gawdzińska K., Chybowski L., Bejger A., Krile S.: Determination of technological parameters of saturated composites based on sic by means of a model liquid, Metalurgija, 55 (2016) 659-662. 
[17] Chybowski L.: A note on modifications to the methodology for components in the complex technical systems reliability structure importance evaluation, J. Polish CIMAC, 6 (2011) 59-64.

[18] Gawdzińska K., Grabian J., Gucma M., Kwiecińska B.: Deformation mechanisms in metal composite foams, Metalurgija, 55 (2016) 37-40.

\section{Acknowledgments}

The research presented in this article was carried out in the Maritime University of Szczecin under the Grant 1/S/IESO/17: „Increasing operational effectiveness of complex technical systems by systematic development and implementation of innovations using novel materials and modifying the object's structure". Examination was conducted using research apparatus purchased under the project „Establishment of the Intercollegiate Scientific and Research Laboratory in Stalowa Wola", under the Operational Development Program of Eastern Poland 2007-2013, Priority Axis and Modern Economy, Action 1.3 Supporting Innovation in accordance with agreement No. POPW.01.03.00-18016/12-00.

\section{CHARAKTERYSTYKA METOD WYTWARZANIA ALUMINIOWYCH I MAGNEZOWYCH ODLEWÓW KOMPOZYTOWYCH}

\section{Streszczenie}

Kompozyty metalowe, a w szczególności o osnowie z metali lekkich (jak aluminium i magnez), są obecnie coraz częściej stosowane w różnego typu środkach transportu. Właściwości gotowych wyrobów są ściśle powiązane $\mathrm{z}$ ich technologią wytwarzania. W niniejszej pracy przedstawiono krótki opis technologii odlewów kompozytowych o osnowie aluminiowej i magnezowej, koncentrując się na wadach i zaletach poszczególnych technologii.

Słowa kluczowe: kompozyty metalowe, technologie wytwarzania, aluminium, magnez

DOI: $10.7862 / \mathrm{rm} .2018 .24$

Przestano do redakcji: 24.04 .2018

Przyjęto do druku: 22.06.2018 